\title{
Power generation from chemically cleaned coals: do environmental benefits of firing cleaner coal outweigh environmental burden of cleaning?
}

Ryberg, Morten W.; Owsianiak, Mikolaj; Laurent, Alexis; Hauschild, Michael Zwicky

Published in:

Energy \& Environmental Science

Link to article, DOI:

$10.1039 / \mathrm{c} 5 \mathrm{ee} 01799 \mathrm{~h}$

Publication date:

2015

Document Version

Peer reviewed version

Link back to DTU Orbit

Citation (APA):

Ryberg, M. W., Owsianiak, M., Laurent, A., \& Hauschild, M. Z. (2015). Power generation from chemically cleaned coals: do environmental benefits of firing cleaner coal outweigh environmental burden of cleaning? Energy \& Environmental Science, 8, 2435-2447. https://doi.org/10.1039/c5ee01799h

\section{General rights}

Copyright and moral rights for the publications made accessible in the public portal are retained by the authors and/or other copyright owners and it is a condition of accessing publications that users recognise and abide by the legal requirements associated with these rights.

- Users may download and print one copy of any publication from the public portal for the purpose of private study or research.

- You may not further distribute the material or use it for any profit-making activity or commercial gain

- You may freely distribute the URL identifying the publication in the public portal 
Ryberg, M. W., Owsianiak, M., Laurent, A., \& Hauschild, M. Z. (2015). Power generation from chemically cleaned coals: do environmental benefits of firing cleaner coal outweigh environmental burden of cleaning? Energy Environ. Sci., (8), 2435-2447. http://doi.org/10.1039/C5EE01799H

6 Power generation from chemically cleaned coals: do environmental benefits of firing cleaner 7 coal outweigh environmental burden of cleaning?

8

9 Morten W. Ryberg*, Mikołaj Owsianiak, Alexis Laurent, Michael Z. Hauschild 10 
Power generation from chemically cleaned coals: do environmental benefits of firing cleaner coal outweigh environmental burden of cleaning?

Division for Quantitative Sustainability Assessment, Department of Management Engineering, Technical University of Denmark, Produktionstorvet, Building 424, DK-2800 Kgs. Lyngby, Denmark

* corresponding author

e-mail: moryb@dtu.dk

tel: (+45) 45251636

\section{Abstract}

Power generation from high-ash coals is a niche technology for power generation, but coal cleaning is deemed necessary to avoid problems associated with low combustion efficiencies and to minimize environmental burdens associated with emissions of pollutants originating from ash. Here, chemical beneficiation of coals using acid and alkali-acid leaching procedures is evaluated as a potential coal cleaning technology employing life cycle assessment (LCA). Taking into account the environmental benefits from firing cleaner coal in pulverized coal power plants and the environmental burden of the cleaning itself, it is demonstrated that for a wide range of cleaning procedures and types of coal, chemical cleaning generally performs worse than combustion of the raw coals and physical cleaning using dense medium separation. These findings apply for many relevant impact categories, including climate change. Chemical cleaning can be optimized with regard to electricity, heat and methanol use for the hydrothermal washing step, and could have environmental impact comparable to that of physical cleaning if the overall resource intensiveness of chemical cleaning is reduced by a factor 5 to 10, depending on the impact category. The largest potential of the technology is observed for high-ash lignites, with initial ash content above $30 \%$, for which the environmental benefits from firing cleaner coal can outweigh the environmental burden of cleaning for some impact categories. We recommend for policy makers to use physical cleaning, as this clearly perform environmentally better, but encourage further research into the chemical 
with current and emerging legislation on ash and sulphur content in coal where the removal efficiency from physical cleaning is insufficient.

\section{Broader context}

The use of fossil coal for generation of electricity is a major cause of many environmental problems globally. Pulverized coal-fired power plants currently account for $97 \%$ of total coal-based electricity generation globally, and are expected to constitute a significant proportion of the environmental burden attributable to power generation also in the future. Chemical cleaning of high-ash coals can potentially mitigate some environmental impacts from firing coal in pulverized power plants, as it allows reaching higher ash removal efficiencies as compared to physical cleaning, but virtually nothing is known about whether environmental benefits from firing cleaner coal outweigh environmental burdens of cleaning. Here, life cycle assessment (LCA) is employed to evaluate chemical beneficiation of coals using acid and alkali-acid leaching procedures. The results showed that demineralization is generally not a feasible option for mitigating environmental impacts, including impacts from climate change, except in few cases where regional and local impacts were improved for high-ash coal systems. This work highlights the current issues associated with chemical cleaning technologies and provides recommendations for stakeholders to resolve these.

\section{Introduction}

The use of fossil coal for generation of electricity is a major cause of environmental problems globally. Using life cycle impact assessment, Laurent and Espinosa ${ }^{1}$ showed that, while coal represented $41 \%$ of the global electricity produced in 2011, it contributed to more than $70 \%$ of the associated environmental burden for nearly all impacts on human health and ecosystems. This important contribution may decrease in the future, as the major focus of national policies is to decrease the share of coal in the power mix and to improve environmental performance of coalbased electricity generation ${ }^{2,3}$. The latter include shutting down small, inefficient power plants, imposing the deployment of cleaner coal technologies (CCTs) such as ultra-supercritical plants (e.g. in India, China, or South Africa), enforcing more stringent emission control and standards with respect to emissions of $\mathrm{CO}_{2}, \mathrm{SO}_{2}, \mathrm{NO}_{x}$, particulate matter (PM), or mercury (e.g. in European 
Union, U.S.A., or Indonesia), and introducing carbon capture and storage systems (e.g. in European Union, U.S.A. and Canada) ${ }^{4,5}$.

Despite these initiatives, coal combustion in pulverized coal (PC) fired power plants, that currently accounts for $97 \%$ of total coal-based electricity generation (of which ca. $76 \%$ is old, subcritical power plants), can still be expected to take up a significant proportion of the total environmental burden attributable to power generation ${ }^{3,6}$. Low-rank coals (with ash content above $30 \%$ ) are relatively abundant as compared to high-rank coals and become increasingly important to secure a stable coal supply for power generation in pulverized power plants. ${ }^{7,8,9}$. Their extraction and firing becomes economically favorable as compared to import of high quality coals from elsewhere ${ }^{10,11}$. Extraction and use of low-ranked coals thus takes place in Europe, U.S.A., China and India today, mainly due to depletion of high quality coal reserves and extraction of low rank coal being economically better than import of high quality coals. Power generation in some important coal using countries, including India, China, Czech Republic, Poland, South Africa, Romania and Turkey, currently relies strongly on these low-rank coals ${ }^{12}$

Coal cleaning to reduce ash content, usually below 30\%, is deemed capable to avoid problems associated with low combustion efficiencies and minimize environmental burdens associated with emissions of airborne pollutants ${ }^{13}$. This is true for both old (subcritical) and newer (e.g. supercritical or ultra-supercritical) combustion technologies. Coal cleaning is commercially done using physical methods, such as grinding of the raw coal followed by gravity-based processes (e.g. dense medium separation) and processes based on surface properties (e.g. froth flotation). These methods have relatively low ash removal efficiencies and are generally not suitable to coals where inherent ash-related minerals are finely disseminated in the coal matrix ${ }^{7,13}$. In contrast, chemical cleaning using acid or alkali-acid leaching procedures are applicable to high-ash coals and allow removing ash more efficiently than physical methods. Because of this, chemical coal cleaning is seen as a complementary alternative to physical cleaning, allowing for achieving the required ash removal rates that cannot be achieved by solely using physical cleaning. Since the 1980s, a total of 26 studies have been published with focus on technological aspects of chemical cleaning using acid or alkali-acid leaching procedures (e.g. ${ }^{14-18}$; see Wijaya and Zhang ${ }^{19}$ and Meshram et al. ${ }^{13}$ for reviews). These studies show a great potential for chemical cleaning of coals, with ash removal efficiencies reaching up to ca. 97\%, depending on the initial ash content and process conditions. Chemical cleaning procedures are currently not widely employed at a commercial scale due to high costs associated with the requirements of chemicals and the need for dewatering of the post- 
demineralization fine-sized slurry. To date, only one pilot plant has been constructed in Australia, which from 2010 to 2012 produced ultra clean coal (UCC, with ash content of ca. $0.1 \%$ ) derived from a bituminous coal for application in integrated gasification combined cycle ${ }^{19,20}$. In the future, chemical cleaning procedures can however become attractive also for PC firing combustion technologies, particularly for those coals for which physical beneficiation might not be a sufficient method for ash removal.

Coal cleaning can both improve and decrease the overall environmental performance of coal firing, depending on the type of environmental impact and stage of the coal combustion life cycle considered. Table 1 shows the implications of coal cleaning using chemical methods on environmental performance of power generation from cleaned coals. For example, reduced contents of sulfur and ash in the coal due to chemical leaching will allow reducing emissions of $\mathrm{SO}_{2}$ and $\mathrm{PM}$, thereby decreasing acidifying impacts on terrestrial ecosystems and damages to human health, and increased combustion efficiencies are expected to reduce climate change impacts up to $5 \%{ }^{21}$ due to reduced emissions of $\mathrm{CO}_{2}$ (per unit of electricity produced). By contrast, chemical leaching requires provision of heat and electricity, which can increase climate change impacts and toxicity-related impacts on human health and ecosystems due to the associated emissions of $\mathrm{CO}_{2}$ and toxic substances. These potential tradeoffs between the environmental benefits of firing cleaner coal and the environmental burden of cleaning processes can be quantified using life cycle assessment (LCA). In LCA, resource consumption and emissions of pollutants stemming from the extraction of the raw materials, their manufacture and use or operations up to their end-of-life are inventoried and translated into impact indicator scores using substance-specific characterization factors for various life cycle impact categories. To date, LCA of power generation from coals cleaned chemically has not been reported in the literature.

The aim of this study is to evaluate chemical cleaning of coals using acid and alkali-acid leaching procedures as a potential coal cleaning technology. The focus is on chemical cleaning because of the lack of knowledge about its environmental performance in coal-based power generation; the goal is to provide a holistic environmental assessment of the technology to facilitate well-informed decisions on use of the technology. To illustrate the potential of the technology, all available variants of leaching procedures published so far for bituminous and sub-bituminous coals, and lignites, were compared (i) to each other, (ii) to physical cleaning using dense medium separation, and (iii) to conventional power generation from raw coals. The coals analysed in the 
141 Table 1. Changes introduced by switching from use of raw coal to coal cleaned chemically and their expected consequences for overall environmental performance.

\begin{tabular}{|c|c|}
\hline $\begin{array}{l}\text { Differences induced by switching from raw } \\
\text { coal to coal cleaned chemically }\end{array}$ & Expected consequences on environmental performance \\
\hline \multicolumn{2}{|l|}{ Expected reduction in environmental impacts: } \\
\hline $\begin{array}{l}\text { Reduced airborne emissions from the power } \\
\text { plant }\end{array}$ & $\begin{array}{l}\text { Part of the ash and sulfur embedded in coal is emitted from the power plant as particulate matter } \\
(\mathrm{PM}) \text { in fly ashes, and as } \mathrm{SO}_{\mathrm{x}} \text {. Lower ash and sulfur content will thus reduce } \mathrm{PM} \text { and } \mathrm{SO}_{\mathrm{x}} \\
\text { emissions }{ }^{22} \text {, which is expected to reduce acidification impact on terrestrial ecosystems and } \\
\text { human health effects of particulate matter. }\end{array}$ \\
\hline $\begin{array}{l}\text { Coal content of hazardous metals like } \\
\text { antimony, arsenic, cadmium, chromium, } \\
\text { copper, cobalt, mercury, lead, manganese and } \\
\text { nickel, generally present in trace amounts is } \\
\text { reduced through the cleaning process }{ }^{23}\end{array}$ & $\begin{array}{l}\text { The hazardous trace elements in the coal are emitted during the combustion or as part of the flue } \\
\text { gas residue disposal. Removal of these pollutants will reduce toxic impact to humans and } \\
\text { ecosystems. The environmental benefits of this removal cannot be included in this study because } \\
\text { of missing data on the content of these elements in the uncleaned coal and their removal during } \\
\text { coal cleaning. }\end{array}$ \\
\hline Increased overall power plant efficiency & $\begin{array}{l}\text { Ash influences the overall power plant efficiency mainly via decreased flame temperature, } \\
\text { decreased heat absorption in heat exchangers, and increased deposits of ash as slag on the boiler } \\
\text { heating surfaces. A decrease in the overall power plant efficiency is expected to increase impacts } \\
\text { on climate change, as more carbon has to be fired per unit of electricity produced, which will } \\
\text { increase overall } \mathrm{CO}_{2} \text { emissions. }\end{array}$ \\
\hline Increased life time of the plant & $\begin{array}{l}\text { Reduction in ash content reduces fouling and corrosion of power plant components which } \\
\text { increases the life time of the plant }{ }^{24,25} \text {. This is expected to decrease the need for steel and metals } \\
\text { and thereby reduce impacts on resource (minerals) depletion. }\end{array}$ \\
\hline $\begin{array}{l}\text { Reduced amount of coal transported between } \\
\text { the cleaning site (typically at mine) and the } \\
\text { power plant }\end{array}$ & $\begin{array}{l}\text { Chemical cleaning increases the higher heating value (HHV) of the coal, therefore less coal has } \\
\text { to be transported from the cleaning site to the power plant per unit of electricity produced }{ }^{26} \text {. This } \\
\text { will reduce fuel consumption for the transport and will thereby decrease the associated emissions } \\
\text { of } \mathrm{CO}_{2} \text { and PM. This is expected to lead to reduced fossil depletion and climate change impacts } \\
\text { and respiratory effects on humans. }\end{array}$ \\
\hline \multicolumn{2}{|l|}{ Expected increase in environmental impacts: } \\
\hline Need for heat and electricity for cleaning & $\begin{array}{l}\text { Increased emissions of } \mathrm{CO}_{2} \text { and metals from energy production are expected to increase climate } \\
\text { change impacts and toxic impacts on human health and ecosystems, depending on the energy } \\
\text { source. }\end{array}$ \\
\hline $\begin{array}{l}\text { Need for } \mathrm{NaOH} \text {, acids, methanol and water for } \\
\text { cleaning }\end{array}$ & $\begin{array}{l}\text { Extraction of raw materials and production of feedstock will lead to increased demand for natural } \\
\text { gas and water. This is for instance expected to increase land use impacts and fossil depletion from } \\
\text { natural gas extraction. }\end{array}$ \\
\hline
\end{tabular}

\section{Methods}

\subsection{Life cycle assessment}

The LCA was conducted in accordance with the requirements of the ISO standard ${ }^{27}$ and the guidelines of the ILCD handbook ${ }^{28}$. The functional unit is defined as the "output to high voltage grid of $1 \mathrm{MJ}$ of electricity produced from a pulverized coal power plant”. Power generation from chemically cleaned coals using various acid or alkali-acid leaching procedures was compared to power generation from coals cleaned physically using dense medium separation (gravity-based process), and to power generation from raw coals. Power generation from coal cleaned using dense 
medium separation is the most widely used physical cleaning method of coal. Power generation from high-ash raw coal is rare, but is reported to take place in India ${ }^{13}$.

Europe was chosen as the primary geographical scope of the assessment. However, as part of a sensitivity check, the comparisons were made using U.S.A. and China as alternative regions to test the validity of our conclusions and whether they change for other geographical regions. U.S.A and China were chosen as these are among the largest coal users worldwide ${ }^{29}$. The system boundaries include the whole life cycle of the power generation, from the construction of the PC power plant and the extraction and supply of bituminous coal, sub-bituminous coal and lignite, through the cleaning process, to coal firing the plant, slag disposal, and decommissioning of the plant. In chemical cleaning, coal is first crushed using a hammer mill as crusher, and then leached in one step with an acid (acid leaching) or in two steps with first alkali and then acid (alkali-acid leaching) to dissolve and remove inert materials in the ash (see ESI † section S1 for details on chemical cleaning). In physical cleaning, coal is first crushed using a hammer mill and is next washed with water to remove inert impurities that are easily accessible and not embedded in the coal matrix ${ }^{30,31}$. Raw coal is only crushed with a hammer mill before firing, but no washing procedure is applied.

The ILCD guidelines provide methodological guidance according to different decision situations, and the current study is in this context considered a micro-level decision support (typeA) situation. The use of chemical demineralization for cleaning of coal is not expected to have large structural changes on the market (e.g. installation of new coal firing capacity or opening new coal mines) compared to current coal practice, at least at the current state of maturity and operation of the chemical cleaning technology. Therefore, the comparison applies an attributional LCA approach, where average data and energy mixes are used. Bituminous and sub-bituminous coals are modelled to represent the European average situation where 78 \% of the coal is extracted in Europe, and the rest is extracted in many parts of the World outside Europe. Lignite combusted in Europe is extracted in European countries only, primarily in Germany, Greece and Poland. Transport via shipping from extraction locations outside of Europe is included, as is storing and raw coal pretreatment, i.e. washing). A European average electricity grid mix is used for the energy supply to the cleaning process and for the coal handling after it has been transported to Europe. Electricity and heat production are modelled as a European average. Alkali and acids that are produced in Europe are modelled for European conditions. Globally produced and traded commodities such as metals needed for construction are modelled as global production. The PC power plant and the subsequent slag treatment are modelled for European conditions. In cases of processes with 
185 recovery of commodities, system expansion was performed, assuming that recovered chemicals 186 (acid and alkali) substitute the production of virgin chemicals, and that ash extracted from coal 187 during chemical cleaning, being a lime product, substitutes virgin lime and gypsum as input for 188 cement production ${ }^{32}$. For U.S.A. and China, different processes were used for coal extraction, 189 electricity generation, and PC power plant technology (see Table S1 in ESI † for more information 190 on the geographical scope).

191 The product systems were modeled in the LCA software GaBi, version 4.3 (PE International, 192 Germany). Environmental impact scores were calculated using the ReCiPe (version 1.05) 193 characterization factors, as implemented in GaBi. 

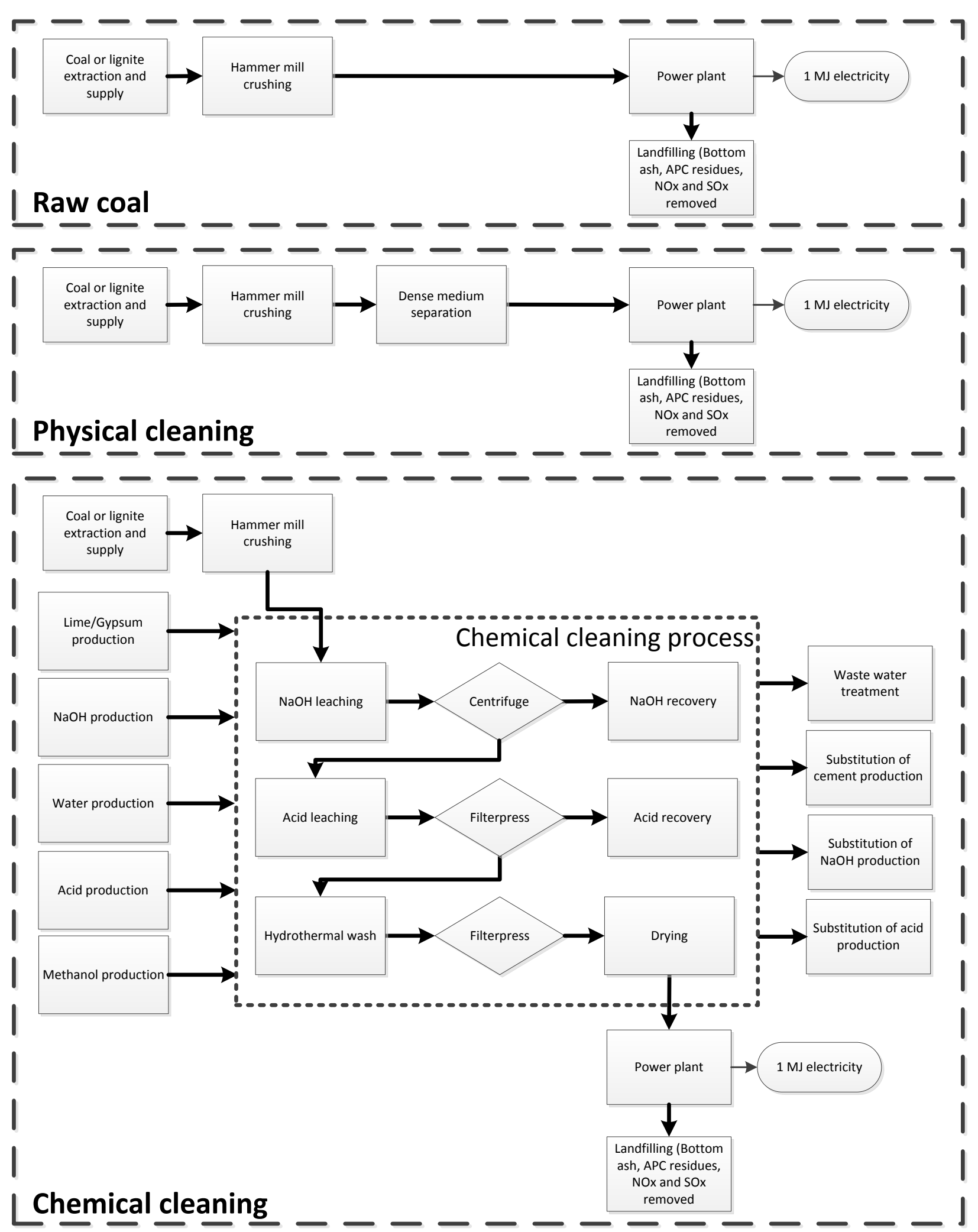

195 Fig. 1. System boundaries for power generation from raw coal (upper), for coal cleaned using

196 physical cleaning (middle) and for coal cleaned using chemical cleaning with acid or alkali-acid 197 leaching (lower). 


\subsection{Data collection and model parameters}

Data on types of equipment for chemical cleaning are based on the full-scale process patented by Brooks et al. ${ }^{33}$, and are combined with data on leaching process conditions, including types and concentration of acids and/or alkali, reaction temperature and duration. This data was retrieved from published studies, available up to September 2014, identified using ISI Web of Knowledge (version 5.7; Thomson Reuters, New York, NY), and were included if the following criteria were met: (i) types of alkali and/or acid are reported, (ii) alkali and/or acid concentrations, cleaning process temperatures and cleaning duration are reported, (iii) initial ash, sulfur, nitrogen, carbon and oxygen contents in the coal are reported, and (iv) final ash contents of the coal are reported. Cited and citing studies that were found to contain relevant data were then consulted to complement the search, and this process was iterated until no new study was found. Studies on cleaning with organic solvent extraction and those with irradiation (such as microwave or ultrasonic) as leaching pretreatment, were excluded. In total, 10 studies $\left({ }^{14-18,34-38}\right)$ were found which met the data requirement criteria. They contain 132 data points for alkali-acid leaching and 107 data points for acid leaching, with 151, 36 and 52 measured data points for bituminous, sub-bituminous and lignite coals, respectively (see section S3 in ESI † for details of the data). Calculated higher heating values (HHV) ranged from 14.9 to $29.5 \mathrm{MJ} / \mathrm{kg}$, depending on the type of coal and the final ash content (Fig. 2). Ash removal efficiencies ranged from 0.05 to 0.97 across all coals, and were the highest for chemical cleaning of high-ash lignites (data not shown).

Model parameters for the processes included within the system boundaries are synthesized in Table 2 and references given. Data for the PC power plant are based on the inventory for a subcritical PC power plant as included in ecoinvent v2.2 ${ }^{39}$ and were modified to reflect the differences between different types of coal with regard to combustion efficiency and emission of pollutants. During combustion, all C, $\mathrm{S}$ and $\mathrm{N}$ compounds were assumed to be oxidized to $\mathrm{CO}_{2}, \mathrm{SO}_{\mathrm{x}}$ and $\mathrm{NO}_{\mathrm{x}}$. Emissions of these gases depend on the installed flue gas cleaning systems, which vary between plants (see Table 2). 


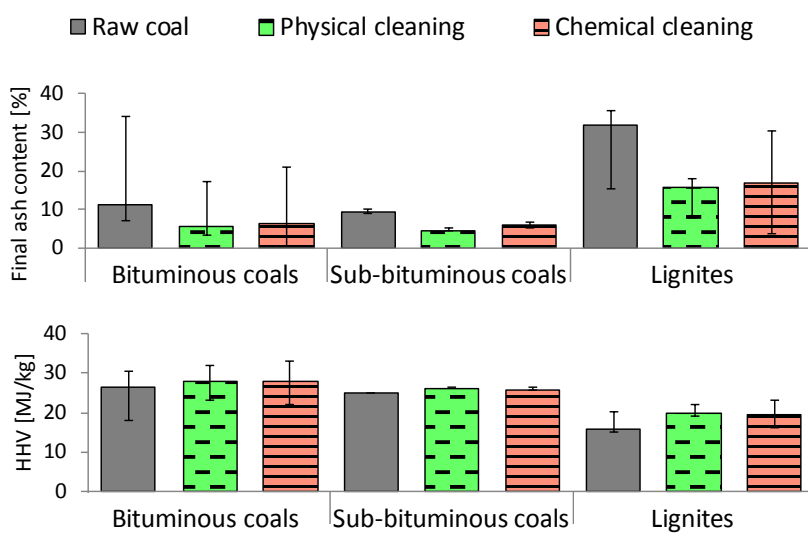

Fig. 2. Final ash content and HHV values of raw and cleaned coals. Error bars indicate the $95 \%$

226 variability intervals. The HHV was calculated using the formula

$227 H H V=0.341 \times C+1.323 \times H+0.0685-0.0153 \times A s h-0.1194 \times(O+N)$ which is based on 700 coal samples,

228 where $C, H, O, N$ and Ash are fractions of the respective element and ash contents in the coal (in $229 \mathrm{~kg}$ element $/ \mathrm{kg}_{\text {coal }}$ and $\mathrm{kg}_{\text {ash }} / \mathrm{kg}_{\text {coal }}$, respectively) ${ }^{40}$. 
230 Table 2. Model parameters and data sources.

\begin{tabular}{|c|c|c|c|c|}
\hline Parameter & $\begin{array}{l}\text { Average (min - } \\
\text { max) }\end{array}$ & Unit & Note & Source \\
\hline \multicolumn{5}{|l|}{ Coal power plant } \\
\hline $\begin{array}{l}\text { Power plant efficiency at } \\
\text { standard ash content }\left(\mathrm{E}_{0}\right)\end{array}$ & $\begin{array}{l}0.366(0.260- \\
0.430)\end{array}$ & $\mathrm{MJ} / \mathrm{MJ}$ & $\begin{array}{l}\text { The power plant efficiency at standard }(6 \%) \text { ash content }\left(\mathrm{E}_{0}\right) \text {. Assumed equal to energy efficiency across } \\
\text { subcritical, supercritical and ultra-supercritical power plants in EU member states (see Table S3 in ESI †). } \\
\text { The average and variability ranges for Europe were also applied for power plants in China and U.S.A. This } \\
\text { choice does not influence the main goal of this study i.e. the comparison between coal cleaning } \\
\text { technologies, but will to some extent influence the environmental performance of coal burning in general }\end{array}$ & 41 \\
\hline $\begin{array}{l}\text { Overall power plant } \\
\text { efficiency (E) }\end{array}$ & $\begin{array}{l}0.362(0.245- \\
0.432)\end{array}$ & $\mathrm{MJ} / \mathrm{MJ}$ & $\begin{array}{l}\text { The overall efficiency of the power plant }(\mathrm{E}) \text { in MJ electricity produced per MJ of thermal input. } \\
\text { Calculated as a product of the plant-specific efficiency at standard ash content }\left(\mathrm{E}_{0}\right) \text { and the coal-specific, } \\
\text { ash-dependent efficiency ratio (ER) using the formula } E=E_{0} \cdot E R\left({ }^{24}\right)\end{array}$ & calculated \\
\hline Efficiency ratio (ER) & $\begin{array}{l}0.988(0.941- \\
1.005)\end{array}$ & $(-)$ & $\begin{array}{l}\text { The efficiency ratio takes into account effects of ash content (Ash, in fraction) on the boiler efficiency, } \\
\text { auxiliary efficiencies, steam efficiency, turbine efficiency and generator efficiency. It increases with } \\
\text { decreasing ash content. Calculated using the formula } E R=1.005-0.05189 \times A s h-0.52841 \times A s h^{2}\left({ }^{24}\right)\end{array}$ & calculated \\
\hline $\begin{array}{l}\text { Flue gas cleaning, NOx } \\
\text { removal efficiency }\end{array}$ & $80(75-85)$ & $\%$ & $\begin{array}{l}\text { Range of values measured for } \mathrm{NO}_{x} \text { removal using selective catalytic reduction (SCR) process, being one of } \\
\text { the most common post-treatment methods. }\end{array}$ & 22 \\
\hline $\begin{array}{l}\text { Flue gas cleaning, SOx } \\
\text { removal efficiency }\end{array}$ & $89(80-98)$ & $\%$ & $\begin{array}{l}\text { Range of values measured for } \mathrm{SO}_{2} \text { removal using flue gas desulfurization (FGD), that utilizes a variety of } \\
\text { slurry or sorbent materials to scrub gases }\end{array}$ & 22 \\
\hline $\begin{array}{l}\text { Flue gas cleaning, PM } \\
\text { removal efficiency }\end{array}$ & $97(95-99)$ & $\%$ & $\begin{array}{l}\text { Range of values for coal power plants, where on average } 3 \% \text { of initial ash content is emitted to air as } \\
\text { particulate matter and the remaining is captured and collected as bottom ash and landfilled }\end{array}$ & ecoinvent v2.2 ${ }^{39}$ \\
\hline \multicolumn{5}{|c|}{ Chemical cleaning using acid or alkali-acid leaching procedures } \\
\hline Centrifuge, electricity use & $1.5(0.03-3.21)$ & $\mathrm{MJ} / \mathrm{m}^{3}$ & $\begin{array}{l}\text { The electricity required for removing liquid from the coal slurry. Values measured for high- and low- } \\
\text { gravity centrifuges of sizes } 74 \times 208 \text { and } 90 \times 225 \text { (cm diameter } \times 208 \mathrm{~cm} \text { length), respectively }{ }^{42} \text {. }\end{array}$ & assumed \\
\hline Filter press, electricity use & $0.88(0.66-1.10)$ & $\begin{array}{l}\mathrm{MJ} / \mathrm{m}^{3} \\
\text { liquid }\end{array}$ & $\begin{array}{l}\text { The electricity required for removing liquid from the coal slurry. Measured for algae recovery }{ }^{43} \text { and } \\
\text { assumed similar in energy used for coal slurry. }\end{array}$ & assumed \\
\hline $\begin{array}{l}\text { Solid content in slurry } \\
\text { after filter press }\end{array}$ & $42.5(35-50)$ & $\%$ & $\begin{array}{l}\text { The solid content present in the coal slurry after filter press, measured for batch filter presses used for } \\
\text { dewatering wastewater with high solids content }{ }^{44}\end{array}$ & assumed \\
\hline $\begin{array}{l}\text { Hydrothermal washing } \\
\text { heat use }\end{array}$ & 3573 & $\begin{array}{l}\mathrm{MJ} / \mathrm{m}^{3} \\
\text { slurry }\end{array}$ & $\begin{array}{l}\text { The energy for heat and electricity used for running the hydrothermal washing process, calculated from } \\
\text { heat equation for a mixture of water, methanol and coal to heated up to } 240^{\circ} \mathrm{C} \text {, as explained in the ESI } \dagger \\
\text { section S5 }\end{array}$ & calculated \\
\hline $\begin{array}{l}\text { Water to methanol ratio } \\
\text { for hydrothermal washing }\end{array}$ & $1: 1$ & $\mathrm{~kg} / \mathrm{kg}$ & $\begin{array}{l}\text { The ratio in which methanol and water are mixed for the hydrothermal washing. A solvent such as } \\
\text { methanol is stated as a requirement by Brooks et al. }{ }^{33} \text { and is applied in the base scenario. However, the } \\
\text { literature providing the data points used is not reporting whether a solvent is used during washing of the } \\
\text { coal, and in many cases only water is applied. We therefore perform a sensitivity test using different ratios } \\
\text { of methanol to water }\end{array}$ & 33 \\
\hline $\begin{array}{l}\text { Liquid (water + methanol) } \\
\text { to coal ratio for } \\
\text { hydrothermal washing }\end{array}$ & $4: 1$ & $\mathrm{~kg} / \mathrm{kg}$ & $\begin{array}{l}\text { The default mixing ratio of water and methanol liquid with coal for the hydrothermal washing as used in } \\
\text { the base scenario }\end{array}$ & 33 \\
\hline Coal drying, heat use & 8.1 & $\begin{array}{l}\mathrm{MJ} / \mathrm{kg} \\
\text { water }\end{array}$ & The energy required for heating and removing water via drying to obtain clean water-free coal & 45 \\
\hline $\begin{array}{l}\text { Ambient liquid } \\
\text { temperature }\end{array}$ & 12 & ${ }^{\circ} \mathrm{C}$ & $\begin{array}{l}\text { The ambient temperature of the liquid used for coal leaching. This affects the energy requirements for } \\
\text { heating the water during demineralization. }\end{array}$ & assumed \\
\hline $\begin{array}{l}\text { Reagents recovery } \\
\text { efficiency }\end{array}$ & 85 & $\%$ & $\begin{array}{l}\text { Alkali and the acids are recovered after the leaching process using lime and gypsum, respectively, The } \\
\text { efficiency of the recovery process for recovery of alkali and acid is based on one source only, hence no } \\
\text { range is provided. } \\
\text { The recovery reactions are as follows: }\end{array}$ & 48 \\
\hline
\end{tabular}




\begin{tabular}{|c|c|c|c|c|}
\hline & & & $\begin{array}{l}\text { Alkali recovery: } \mathrm{Na}_{2} \mathrm{SiO}_{3}+\mathrm{Ca}(\mathrm{OH})_{2} \rightarrow \mathrm{Ca}_{2} \mathrm{SiO}_{3}+2 \mathrm{NaOH} \\
\text { Acid recovery: } \mathrm{H}_{2} \mathrm{SiO}_{3}+\mathrm{CaSO}_{4} \rightarrow \mathrm{CaSiO}_{3}+\mathrm{H}_{2} \mathrm{SO}_{4} \\
32,46,47 \text {. }\end{array}$ & \\
\hline $\begin{array}{l}\text { Reagents recovery } \\
\text { electricity use }\end{array}$ & 0.005 & $\mathrm{MJ} / \mathrm{kg}$ & The electricity use for recovery of alkali and acids & 48 \\
\hline \multicolumn{5}{|l|}{ Acid or alkali concentration } \\
\hline $\mathrm{HCl}$ & $11.6(5.0-30.0)$ & $\%$ & Aqueous concentration of $\mathrm{HCl}$ in the acid leaching step & $\begin{array}{l}\text { various sources (146 data } \\
\text { points, see Table S2 in ESI } \dagger \text { ) }\end{array}$ \\
\hline $\mathrm{HNO}_{3}$ & $19.0(5.0-30.0)$ & $\%$ & Aqueous concentration of $\mathrm{HNO}_{3}$ in the acid leaching step & $\begin{array}{l}\text { various sources ( } 26 \text { data } \\
\text { points, see Table S2 in ESI } \dagger \text { ) }\end{array}$ \\
\hline $\mathrm{H}_{2} \mathrm{SO}_{4}$ & $15.5(5.0-30.0)$ & $\%$ & Aqueous concentration of $\mathrm{H}_{2} \mathrm{SO}_{4}$ in the acid leaching step & $\begin{array}{l}\text { various sources (43 data } \\
\text { points, see Table S2 in ESI } \dagger \text { ) }\end{array}$ \\
\hline $\mathrm{HF}$ & $9.5(1.3-25.5)$ & $\%$ & Aqueous concentration of HF in the acid leaching step & $\begin{array}{l}\text { various sources (14 data } \\
\text { points, see Table S2 in ESI †) }\end{array}$ \\
\hline $\mathrm{H}_{2} \mathrm{O}_{2}$ & $12.5(2.5-30.0)$ & $\%$ & Aqueous concentration of $\mathrm{H}_{2} \mathrm{O}_{2}$ in the acid leaching step & $\begin{array}{l}\text { various sources ( } 10 \text { data } \\
\text { points, see Table S2 in ESI } \dagger \text { ) }\end{array}$ \\
\hline $\mathrm{NaOH}$ & $28.5(2.0-98.0)$ & $\%$ & Aqueous concentration of $\mathrm{NaOH}$ in the alkali leaching step & $\begin{array}{l}\text { various sources (132 data } \\
\text { points, see Table S2 in ESI †) }\end{array}$ \\
\hline $\begin{array}{l}\text { Temperature of the acid } \\
\text { leaching step }\end{array}$ & $84.5(25.0-100.0)$ & ${ }^{\circ} \mathrm{C}$ & The temperature during the acid leaching & $\begin{array}{l}\text { various sources (239 data } \\
\text { points, see Table S2 in ESI } \dagger \text { ) }\end{array}$ \\
\hline $\begin{array}{l}\text { Duration of acid leaching } \\
\text { step }\end{array}$ & $2.4(0.2-8.0)$ & hours & The duration of the acid leaching & $\begin{array}{l}\text { various sources (239 data } \\
\text { points, see Table S2 in ESI } \dagger \text { ) }\end{array}$ \\
\hline $\begin{array}{l}\text { Temperature of alkali } \\
\text { leaching step }\end{array}$ & $146.4(85.0-210.0)$ & ${ }^{\circ} \mathrm{C}$ & The temperature during the alkali leaching step & $\begin{array}{l}\text { various sources (132 data } \\
\text { points, see Table S2 in ESI } \dagger \text { ) }\end{array}$ \\
\hline $\begin{array}{l}\text { Duration of alkali leaching } \\
\text { step }\end{array}$ & $1.7(0.5-24.0)$ & hours & The duration of the alkali leaching step & $\begin{array}{l}\text { various sources (132 data } \\
\text { points, see Table S2 in ESI } \dagger \text { ) }\end{array}$ \\
\hline $\begin{array}{l}\text { Sulfur reduction efficiency } \\
\text { due to chemical cleaning }\end{array}$ & $20(9-48)$ & $\%$ & $\begin{array}{l}\text { Reduction of sulfur content in the coal as a function of alkali-acid leaching predicted from } \mathrm{NaOH} \\
\text { concentration, acid concentration, time of alkali leaching and time of acid model using a model developed } \\
\text { based on literature data (see ESI } \dagger \text { section S6). The model has been validated against external data, and its } \\
\text { predictive power corresponds to a predictive squared correlation coefficient for external validation }\left(\mathrm{Q}^{2}\right) \\
\text { equal to } 0.8 \text {. }\end{array}$ & calculated \\
\hline $\begin{array}{l}\text { Nitrogen reduction } \\
\text { efficiency due to chemical } \\
\text { cleaning }\end{array}$ & 0 & $\%$ & $\begin{array}{l}\text { No nitrogen reduction considered, as literature on nitrogen content from chemical demineralization is } \\
\text { inconclusive. A number of sources state that nitrogen content increases with alkali-acid leaching }{ }^{19,49,50} \text {. } \\
\text { This has only been shown where nitric acid is used, in these cases the nitrogen containing acid may react to } \\
\text { form nitrogen-bearing species within the coal }{ }^{50} \text {. }\end{array}$ & assumed \\
\hline \multicolumn{5}{|c|}{ Physical cleaning using dense medium separation (gravity-based method) } \\
\hline Ash removal efficiency & $50(16-68)$ & $\%$ & $\begin{array}{l}\text { The ash removal efficiency from the coal after physical cleaning using dense medium separation measured } \\
\text { for various dense medium separation procedures. }\end{array}$ & 51 \\
\hline Sulfur removal efficiency & $48(10-84)$ & $\%$ & $\begin{array}{l}\text { The sulfur removal efficiency from the coal after physical cleaning measured for various dense medium } \\
\text { separation procedures. }\end{array}$ & 51 \\
\hline Electricity use & $\begin{array}{ll}0.027(0.022- \\
0.032)\end{array}$ & $\begin{array}{l}\mathrm{MJ} / \mathrm{kg} \text { coal } \\
\text { treated }\end{array}$ & $\begin{array}{l}\text { The electricity use for physical cleaning of coal at mine measured for a dense medium separation } \\
\text { procedures process. }\end{array}$ & 52 \\
\hline \multicolumn{5}{|l|}{ Transportation } \\
\hline $\begin{array}{l}\text { From coal storage to } \\
\text { power plant }\end{array}$ & 100 & $\mathrm{~km}$ & By lorry & assumed \\
\hline $\begin{array}{l}\text { From coal storage to } \\
\text { demineralization plant }\end{array}$ & 10 & $\mathrm{~km}$ & By lorry & assumed \\
\hline $\begin{array}{l}\text { From demineralization } \\
\text { plant to power plant }\end{array}$ & 100 & $\mathrm{~km}$ & By lorry & assumed \\
\hline
\end{tabular}


Sensitivity of impact scores to uncertain or variable model parameters was done by calculating

$$
S_{\text {coef }}=\frac{\Delta I S}{I S_{0}} / \frac{\Delta a_{k}}{a_{k, 0}}
$$

where $a_{k, 0}$ is the input parameter value, $I S_{0}$ is the impact score calculated for the $a_{k, 0}, \Delta a_{k}$ is the difference between the default input parameter and the perturbed input parameter, $\Delta I S$ is the difference between $I S_{0}$ and the impact score calculated for the perturbed parameter value. All input parameters were perturbed by 25\%. All parameters in Table 2 were included in the sensitivity analysis. Among all 239 chemical cleaning combinations, the $S_{\text {coef }}$ was calculated for a total of 16 combinations, selected to represent a range of chemical cleaning process conditions, (i.e. the highest and the lowest values of: $\mathrm{NaOH}$ concentration, acid concentration, time of the alkali leaching step, temperature of the alkali leaching step, time of the acid leaching step, and temperature of the acid leaching step), a range of initial ash contents (i.e. the highest and lowest initial ash content) and a range of ash removal efficiencies (i.e. the highest and the lowest ash removal efficiency). A parameter is considered important if average $\left|S_{\text {coef }}\right| \geq 0.3$, or if the largest $\left|S_{\text {coef }}\right| \geq 0.5$, corresponding

\subsection{Uncertainty and variability analysis}

252 Parameter uncertainties stem from the lack of knowledge about the actual value of a parameter ${ }^{56}$, 253 e.g. electricity use of a centrifuge. By contrast, variability is the inherent variance that will exist 254 between similar processes depending on technological level and spatial location, e.g. power plant 255 efficiency at standard ash content ${ }^{56}$. Here, parameter uncertainty was assessed together with variability by means of a Monte Carlo analysis, using parameters which were found important in the sensitivity analysis (Table 3). They were assigned standard deviations based on the min-max ranges in Table 2, accounting for their uncertainty and variability. Normal distributions were assumed. Differences in impact scores between the compared systems were considered significant if the 
261 Table 3. Uncertain or variable parameters included in the Monte Carlo simulation and the associated relative standard deviation.

\begin{tabular}{|c|c|c|}
\hline Uncertain or variable parameter & $\begin{array}{l}\text { Average (relative } \\
\text { standard deviation) }\end{array}$ & Note \\
\hline Efficiency of NOx removal & $0.8(6 \%)$ & Based on literature $^{22}$ \\
\hline Efficiency of SOx removal & $0.89(10 \%)$ & Based on literature $^{22}$ \\
\hline Power plant efficiency & $0.366(12 \%)$ & $\begin{array}{l}\text { Mean and standard deviation are based on power plant overall efficiencies of } \\
\text { European countries } 41\end{array}$ \\
\hline Centrifuge electricity use & $1.5(30 \%)$ & Based on literature $^{42}$ \\
\hline Filter press electricity use & $0.88(25 \%)$ & $\begin{array}{l}\text { Based on }{ }^{43} \text {, because variability ranges were not available, a relative standard } \\
\text { deviation of } 25 \% \text { is assumed to account for large variations }\end{array}$ \\
\hline $\begin{array}{l}\text { Sodium hydroxide recovery } \\
\text { efficiency }\end{array}$ & $0.85(25 \%)$ & $\begin{array}{l}\text { Based on }{ }^{48} \text {, because variability ranges were not available, a relative standard } \\
\text { deviation of } 25 \% \text { is assumed to account for large variations, varying between a } \\
\text { recovery efficiency of } 64-100 \%\end{array}$ \\
\hline Acid recovery efficiency & $0.85(25 \%)$ & $\begin{array}{l}\text { Based on }{ }^{48} \text {, because variability ranges were not available, a relative standard } \\
\text { deviation of } 25 \% \text { is assumed to account for large variations, varying between a } \\
\text { recovery efficiency of } 64-100 \%\end{array}$ \\
\hline Physical ash removal efficiency & $0.50(33 \%)$ & $\begin{array}{l}\text { The fraction of ash left in coal after mechanical treatment at mine, using crushing } \\
\text { and gravity separation }{ }^{51}\end{array}$ \\
\hline Mechanical sulfur removal efficiency & $0.52(26 \%)$ & $\begin{array}{l}\text { The fraction of sulfur left in coal after mechanical treatment at mine, using } \\
\text { crushing and gravity separation }{ }^{51}\end{array}$ \\
\hline
\end{tabular}

\section{Results and discussion}

Below, we present results for four selected impact categories, which represent typical impact profiles observed for all 18 impact categories (results for all impact categories are presented in Fig. S2 in ESI †). Next, the potential of the chemical cleaning technology as a coal beneficiation method, and the broader applicability of our findings, are discussed.

\subsection{Does coal cleaning bring environmental benefits?}

274 Fig. 3 shows that, irrespective of the initial ash content, coals cleaned chemically perform significantly worse in an overall life cycle perspective than raw coals and coals cleaned physically for the impact category climate change. For acidification impacts on terrestrial ecosystems and impacts from PM on human health, impact scores overlap, whereas for freshwater ecotoxicity (toxic impacts on freshwater ecosystems), the environmental performance of the chemically cleaned coal depends on the initial ash content of the coal: for low-ash coals chemical cleaning performs worse as compared to raw coal, and the opposite is observed for high-ash coals. Further, freshwater ecotoxicity impact scores for coals cleaned chemically peak at $30 \%$ of initial ash content. 
The increase in impact scores with initial ash content up to 30\% for freshwater ecotoxicity (but also for freshwater eutrophication, PM formation and other toxicity-related impact categories, see Fig. S2 in ESI †) is primarily caused by emissions of particles and leaching of heavy metals and phosphate from landfilling of residual (bottom) ash. These emissions are naturally higher for highash coals. Thus, there is some potential for avoiding environmental problems caused by firing coals if the ash is separated from the coal before the firing. Indeed, the decrease in impact scores for chemically cleaned high-ash coals (containing $>30 \%$ ash in raw coal) is due to a very efficient 289 cleaning of lignites, for which up to $90 \%$ ash removal efficiency can be reached using acid or alkaliacid leaching procedures ${ }^{17}$. In contrast, the ash removal efficiency for physical cleaning generally does not depend on the coal type, which explains why environmental performance of high-ash lignites cleaned chemically improves relative to these coals cleaned physically.
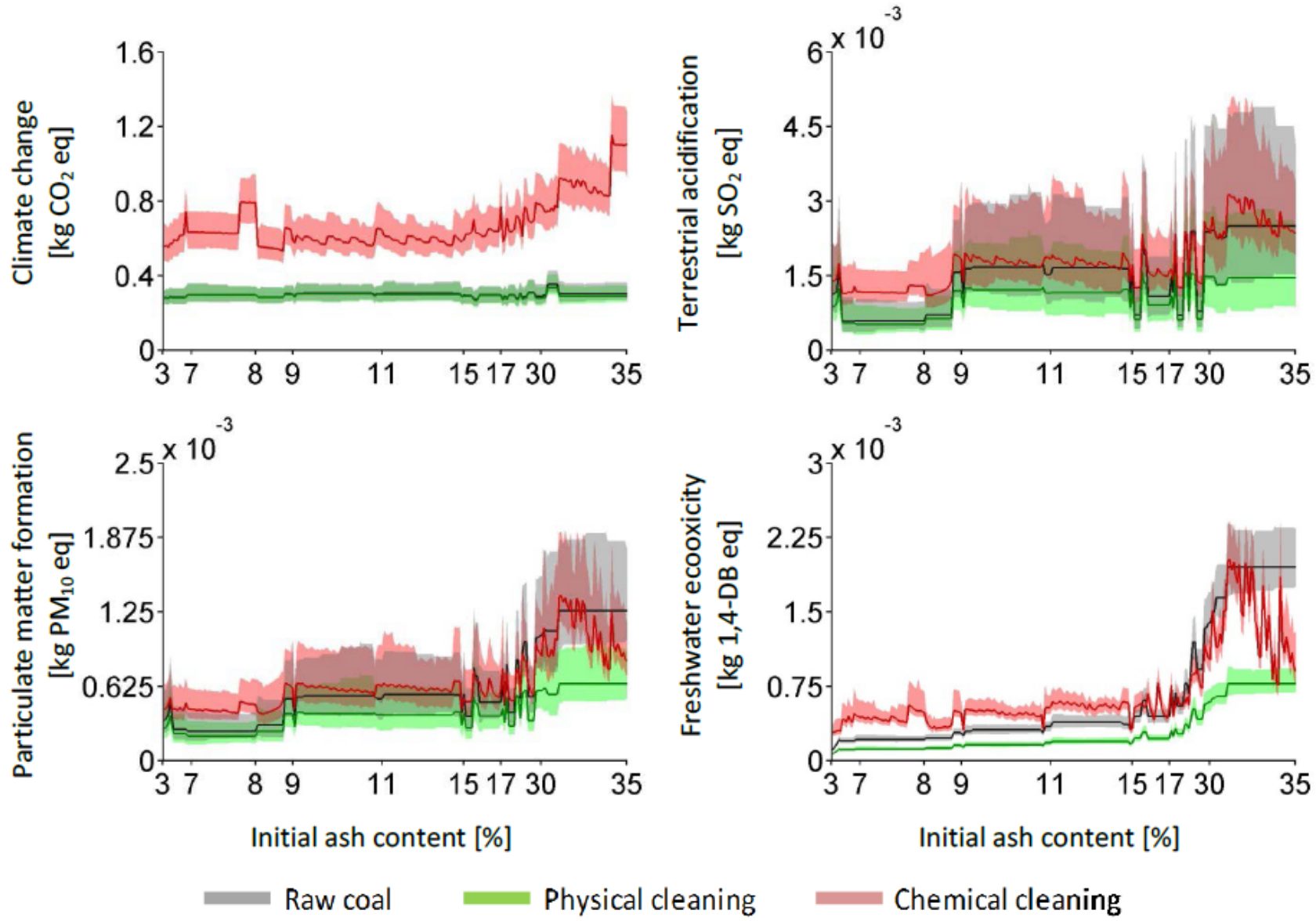

Fig. 3. Impact scores and the associated 95\% confidence intervals per functional unit ("output to 
298 of ash content in the raw coal, shown for each of the four selected impact categories. The results are 299 shown for the European scenario.

300

- Coal extraction

$\square$ Coal combustion

$\square$ Coal slag disposal

Demineralization: Methanol production

Demineralization: Alkali, acid, lime production and recovery

$\square$ Demineralization: Other

$\square$ Demineralization: Electricity use

Demineralization: Heat use

$\square$ Transportation
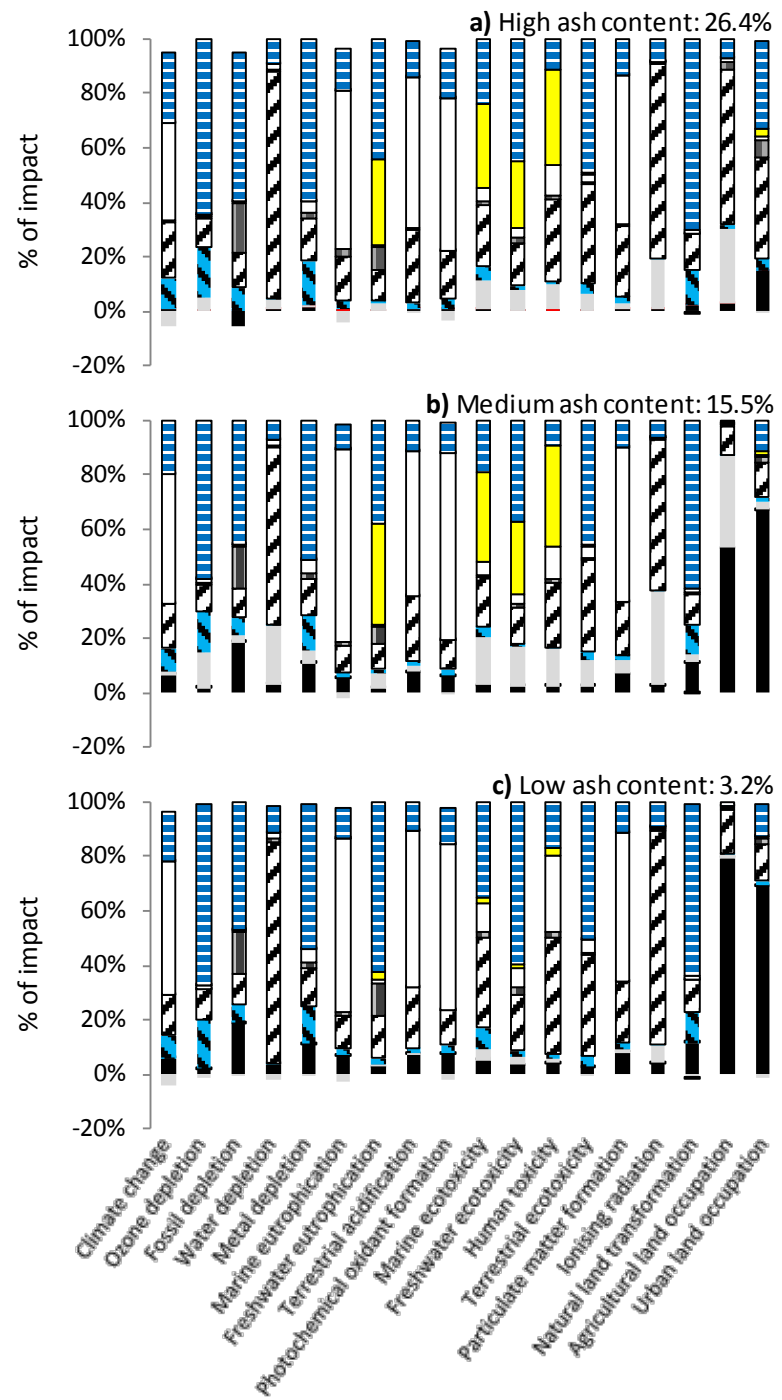

302 Fig. 4. Contribution of life cycle processes to total impact scores for coal firing using chemical 303 cleaning (alkali-acid leaching) of coals with different initial ash contents. The results are shown for 304 the European scenario. 


\subsection{Can chemical cleaning become an environmentally sound approach for coal} beneficiation?

308 Despite the potential benefits of chemical cleaning of high-ash coals for some impact categories, 309 our results show that burden shifting might occur if only environmental problems directly caused by ash are considered. Indeed, impact scores for other relevant impact categories including climate

311 change and depletion of resources (land, water, minerals and fossils) are increased when ash is removed before firing (see Fig. 3 and Fig. S2 in ESI †). Such trends are caused by non-ash-related emissions, which have large contributions in other environmental impacts and stem from the cleaning process. For example, while the reduction in PM emissions from the firing of the chemically-cleaned lignites outweigh the increase in PM emissions from the cleaning processes, thus resulting in an overall decrease of impact scores for the PM formation impact category, the opposite trend is observed for climate change and other impact categories (see Fig. 3). Improvements in the environmental performance of chemical cleaning should therefore focus on optimization of cleaning procedures in order to minimize all relevant environmental impacts.

To identify improvement potentials for the chemical cleaning technology a process contribution analysis was conducted, i.e. identifying the processes with the largest environmental burden. Fig. 4 shows that the largest contributors to environmental impacts are (i) the electricity consumption for centrifugation in the alkali step of the leaching procedure, and (ii) the production of methanol for the hydrothermal washing step of the cleaning procedure. The contributions of these two processes were above $50 \%$ of the total impact score for many impact categories. The sensitivity analysis further confirmed that these processes had the largest influence on impact scores (see Table S6 in ESI $\dagger$ ). Hence, there is a potential for improving the environmental performance of the chemical cleaning technology if the electricity demand for chemical demineralization and the methanol use for the hydrothermal washing step are optimized.

In our study of chemical cleaning we had to rely on data from the pilot scale process combined with parameters retrieved from laboratory measurements and estimations based on physical relationships (e.g. energy required for heating a liquid solution). However, commercial scale processes are often seen to have smaller environmental impacts due to the use of more efficient use of processes and feedstock ${ }^{58}$ compared to laboratory scale where efficiency is less important and focus is on developing the cleaning process and achieving useful results. Thus, it cannot be ruled out that the overall demand for chemicals and energy will be smaller when chemical cleaning is performed at commercial scale. Because chemical cleaning is still a relatively new and immature 
technology some improvement with regard to use of energy and feedstock as a result of upscaling can be expected. Yet, our analysis shows that a reduction in total electricity and heat use in chemical cleaning by a factor of 5 to 10, depending on the impact category would make chemical cleaning perform comparably to physical cleaning; this is illustrated in Fig. 5-1 for the climate change impact category. Achieving such reduction poses a strong challenge for the technology and seems unlikely. For petrochemical production processes, which share some similarities with chemical cleaning (e.g. centrifuge, filtering and heating), the energy consumption can be reduced by $16 \%$ - $20 \%$ by adopting best available technologies (BAT) ${ }^{59,60}$. The heat demand from upstream sources can be reduced by utilizing low grade waste heat (energy pinching), which is estimated to increase energy efficiency by circa a factor $1.2^{61-64}$, while electricity efficiency may be increased by use of kinetic energy recovery systems or improving the efficiency of electricity using systems, this can yield electricity savings between $5 \%-40 \%{ }^{64,65}$.

Methanol is produced from natural gas, through synthesis gas, which is then converted to methanol using metal oxide catalysts ${ }^{39,66}$. Because methanol is a key intermediary product and is vital for the production of many globally-used commodities (e.g. formaldehyde and solvents), finding cleaner alternatives for methanol appears unlikely. However, the use of a solvent such as methanol during the hydrothermal washing step is not absolutely necessary; Mukherjee ${ }^{67}$ already showed that alkali-acid cleaning combined with washing in a methanol solution did not show improved cleaning efficiencies compared to similar alkali-acid leaching studies where the same coal was washed with pure water ${ }^{18,34,38}$. We therefore tested if excluding methanol from the cleaning procedure improves environmental performance of chemical cleaning. Figure 5-2 shows that although methanol contributes substantially to a number of impact categories, the influence of excluding it from the hydrothermal washing step on impact scores is modest. This is because chemical cleaning generally perform worse than physical cleaning for the impact categories where methanol is found to be an important contributor, and whether methanol is included makes little difference on the comparison (see ESI Fig. S2). Thus, while phasing out methanol and replacing it with water is overall an important improvement of the cleaning procedure, it is not sufficient for chemical cleaning to perform better as compared to physical cleaning

Developers of leaching procedures typically focus on optimizing reaction conditions and selection of appropriate acids, which in this study are seen to have relatively small contribution to total environmental impacts and are not seen to influence impact scores significantly ( $\mathrm{S}_{\text {coef }}$ typically below 0.1, see Section S9 in ESI †). Thus, from the environmental performance perspective, higher 
concentrations of acids and alkali and higher leaching temperatures and durations can be justified if they allow for increasing ash removal efficiencies and thereby increasing the environmental benefits associated with firing cleaner coal. This is observed for lignites, of which many have their initial ash content equal to 35\%: more severe cleaning conditions with regard to temperatures and concentrations of chemicals do not translate into higher environmental impacts.

In summary, chemical cleaning is not likely to become an environmentally sound approach for coal beneficiation, unless developers of chemical cleaning procedures (i) use water instead of methanol in the washing step, (ii) focus on achieving very high ash removal efficiencies by optimizing the use of alkali and acids, and (iii) find more attractive, environmentally speaking, ways of separating liquid from coal slurry after each washing steps.

\subsection{Applicability of the findings for other geographic locations}

Our conclusions about the overall poor performance of chemical cleaning are not expected to change when assuming coal power production in U.S.A. or China. Even though impact scores for these two countries are higher for many impact categories as compared to Europe, chemical cleaning is generally seen as the worst alternative in terms of environmental impacts. However, for terrestrial acidification impacts (see Fig. 5), PM formation and marine eutrophication in the Chinese scenario, impact scores for chemical cleaning are lower than those for the raw coal (data not shown). Chinese plants in our model have lower $\mathrm{SO}_{2}$ cleaning efficiencies and PM removal efficiencies. Hence chemical cleaning becomes environmentally beneficial as it allows removing a part of sulfur and ash from the coal that otherwise would have been emitted as $\mathrm{SO}_{2}$ and $\mathrm{PM}$. This could suggest that chemical cleaning could be an environmentally sound technology for ash removal in regions where pollutant emission regulations are not as stringent as in Europe. However environmental burden shifting might still occur as for other impact categories, just as for climate change, chemical cleaning performs worse than physical cleaning or firing of raw coal.

The overall power plant efficiency was by far the most influential parameter (with $S_{\text {coef }}$ equal to -0.8 for all impact categories), hence, an increase in the overall power plant efficiency will reduce environmental burdens associated with power generation. However, simply shifting to a power plant with a higher overall efficiency will not make chemical cleaning an environmentally sound coal beneficiation options, unless large reductions in combustion efficiencies due to high ash contents are observed for highly-efficient plants. Such situations, however, do not apply to PC power plants. Yet, a reduction of ash content below $0.1 \%$ allows coal firing in an integrated 

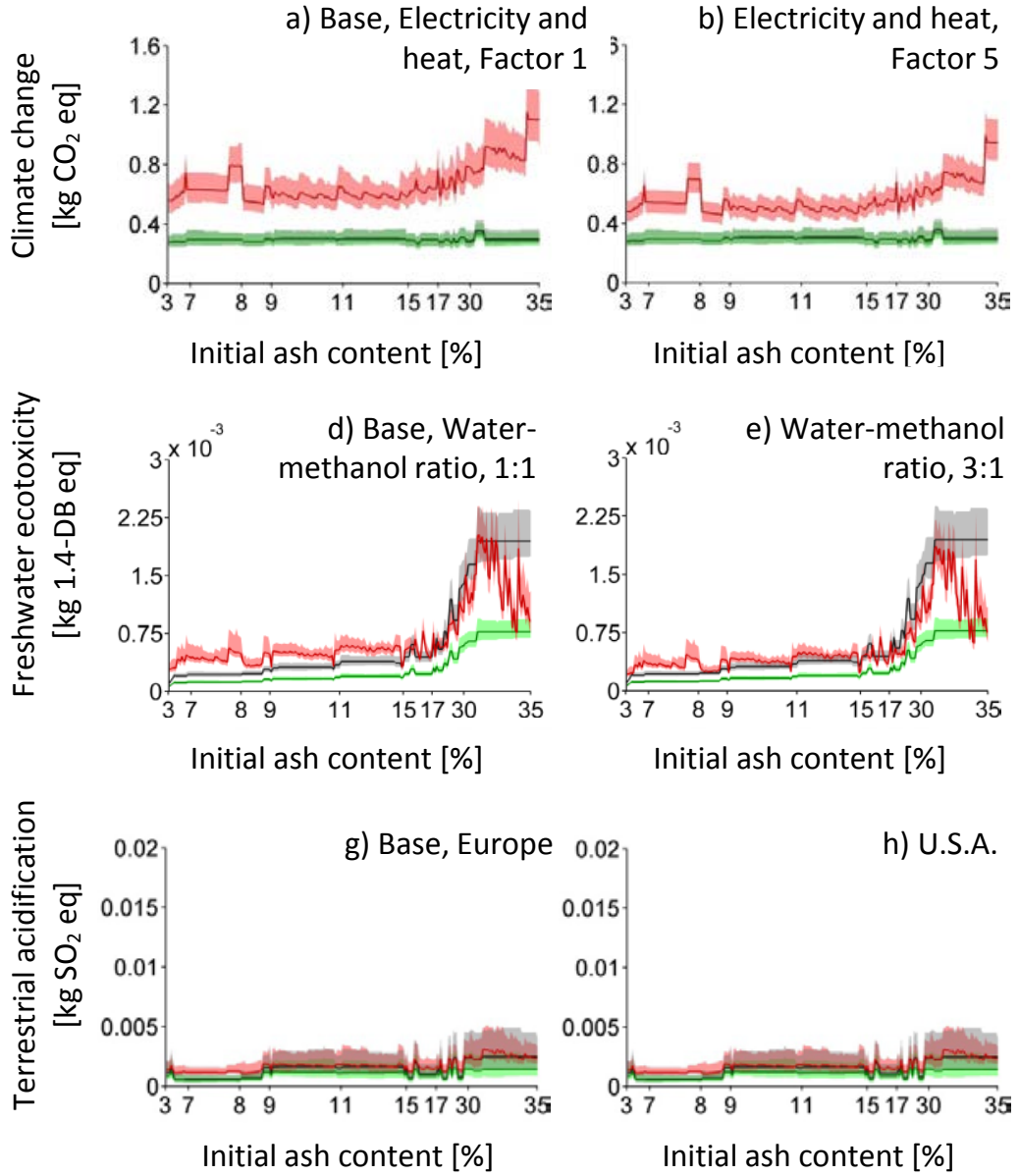
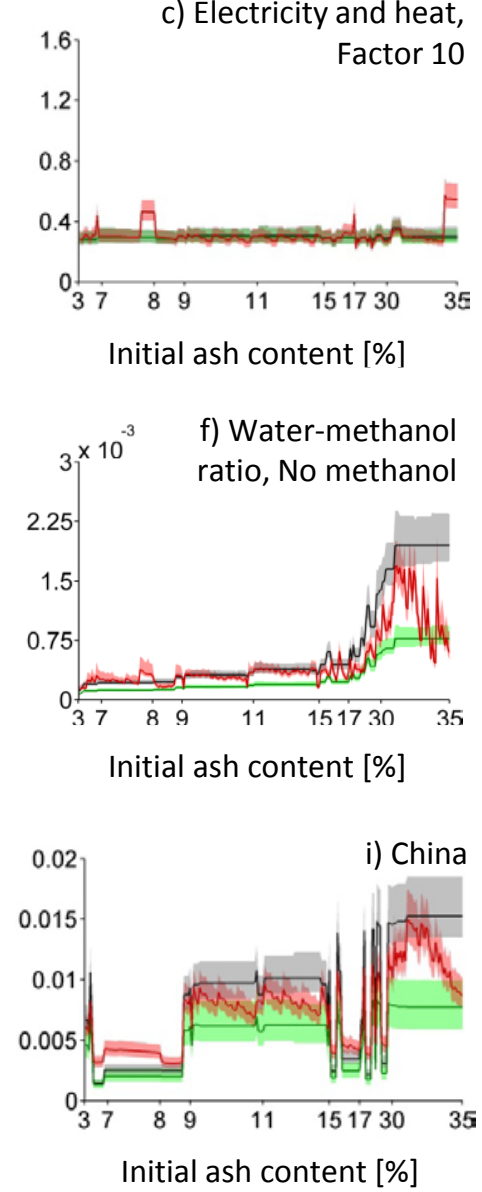

Chemical cleaning

Fig. 5. Impact scores for climate change in the European scenario are shown for a) the base scenario, b) for the scenario where the electricity and heat use for chemical cleaning was reduced by a factor 5 and c) for the scenario where the electricity and heat use was reduced by a factor 10 . 410 Underneath, impact scores for freshwater ecotoxicity in the European scenario are shown in d) for 411 the base scenario using 1:1 water to methanol ratio, in e) using 3:1 water to methanol ratio and in $\mathbf{f}$ ) 412 where methanol is excluded and only water is used during the hydrothermal wash. Finally, impact 413 scores for terrestrial acidification are shown for three different geographical scopes $\mathbf{g}$ ) the base 414 scenario i.e. Europe, h) U.S.A. and i) China. 


\section{Conclusions and recommendations for policy makers}

417 The increased use of low rank coals for power generation has resulted in the implementation of

418 stricter legislation on ash and sulphur contents in the coal, primarily to reduce air pollution and 419 transport costs. For instance, as part of the "Interim Measures on the Management of Commercial

420 Coal Quality“, China has imposed restrictions on ash and sulphur contents in lignites for

421 commercial use which must stay below 30\% and 1.5\% respectively to reduce emissions from coal

422 burning $^{68}$. India has banned coal with ash content above $34 \%$ in order to reduce impacts and costs

423 from the often long transports inside the country ${ }^{10}$. Increased research and development of

424 chemical coal cleaning has been recommended in a report to the U.S. Secretary of Energy by the

425 National Coal Council, NCC ${ }^{69}$ (which serves as an advisory council to the Secretary of Energy and

426 NCC members comes from both industry and academia). This new legislation is expected to

427 increase demand for chemical cleaning technologies in the future, particularly for high-ash coals

428 with ash and sulphur being strongly embedded in the coal matrix, for which physical cleaning is not

429 sufficient method for cleaning. Yet, as we showed that chemical cleaning of coals for firing in PC

430 power plants in general is not an environmentally sound option for coal beneficiation, we

431 recommend policy makers that coal cleaning using acid or alkali-acid leaching procedures should

432 not be considered for direct implementation as a coal beneficiation technology. We note, however,

433 that chemical cleaning is a relatively immature technology and, as showed, its environmental

434 performance of chemical cleaning is expected to improve when upscaling from the laboratory scale

435 to the commercial scale is done. These improvements can be achieved by phasing out methanol in

436 the washing step, increasing higher ash removal efficiencies by optimizing the use of alkali and

437 acids, and finding more attractive, environmentally speaking, ways of separating liquid from coal

438 slurry after each washing step. When these measures are undertaken, chemical cleaning might

439 become environmentally attractive technology that can complement physical cleaning methods for

440 ash removal for high-ash, difficult to treat coals. We stress that life cycle based approaches, such as

441 LCA must be used to determine for which coals and cleaning procedures, chemical cleaning can be

442 considered as potential beneficiation technology to avoid environmental burden shifting which

443 occurs when environmental benefits of firing cleaned coal do not outweigh environmental burden of

444 the cleaning. Finally, for high-ash coals where ash is relatively easy to remove and for coals with

445 low ash content, we recommend policy makers to focus on physical methods of cleaning. They

446 clearly perform better in a life cycle perspective as compared to chemical cleaning or combustion of 
raw coal and it is not likely that they will be able to compete with physical cleaning in terms of environmental performance even when eco-design measures are undertaken.

\section{Notes and References}

$452 \dagger \quad$ Electronic Supplementary Information (ESI) available: Supplementary Methods (Figure S1;

1 A. Laurent and N. Espinosa, Energy Environ. Sci., 2015, 8, 689-701.

2 E. G. Hertwich, T. Gibon, E. a. Bouman, A. Arvesen, S. Suh, G. a. Heath, J. D. Bergesen, A. Ramirez, M. I. Vega and L. Shi, Proc. Natl. Acad. Sci., 2014, 201312753, DOI: 10.1073/pnas.1312753111.

3 IEA, Energy technology perspectives 2012 : pathways to a clean energy system, OECD/IEA, 2012.

4624 IEA, 21 Century Coal, International Energy Agency - Coal Industry Advisory Board, 2013.

4635 IEA, Technology Roadmap - Carbon capture and storage, International Energy Agency, 4642013.

$4677 \quad$ N. S. Dong, Utilisation of Low Rank Coals, IEA Clean Coal Centre, 2011.

4688 R. Kurose, M. Ikeda and H. Makino, Fuel, 2001, 80, 1447-1455.

4699 H. Tsuji, H. Shirai, H. Matsuda and P. Rajoo, Fuel, 2011, 90, 850-853.

47111 IEA, Coal information 2012, International Energy Agency - Coal Industry Advisory Board, $472 \quad$ Paris Cedex, 2012.

47312 K. Burnard and S. Bhattacharya, Power generation from coal - Ongoing development and outlook, International Energy Agency - IEA, Paris Cedex, 2011. 
15 P. S. Dash, S. S. Kumar, P. K. Banerjee and S. Ganguly, Miner. Process. Extr. Metall. Rev., 2013, 34, 223-239.

H. Karaca and Y. Önal, Fuel, 2003, 82, 1517-1522.

M. Çulfaz, M. Ahmed and S. Gürkan, Fuel Process. Technol., 1996, 47, 99-109.

N. Wijaya and L. Zhang, Energy \& Fuels, 2011, 25, 1-16.

UCC Energy - Yanzhou Coal Mining Limited, http://uccenergy.net/ucc-pilot-plant/, (accessed March 2015).

IEA, 2008, DOI: 10.1787/9789264077164-en.

A. Franco and A. R. Diaz, Energy, 2009, 34, 348-354.

P. J. Reddy, Clean coal technologies for power generation, 2013.

M. S. Bhatt, Energy Sources, Part A Recover. Util. Environ. Eff., 2006, 28, 25-41.

T. Hulgaard and J. Vehlow, in Solid Waste Technology \& Management, ed. T. H. Christensen, John Wiley \& Sons, Ltd, 2010, pp. 363-392.

ISO, 14044: environmental management-life cycle assessment-requirements and guidelines, International Organization for Standardization, 2006.

28 EC-JRC, General guide for life cycle assessment-detailed guidance. ILCD HandbookInternational Reference Life Cycle Data System, European Union EUR 24708 EN.

Publications Office of the European Union http://lct.jrc.ec.europa.eu/, Luxembourg, First., 2010.

IEA, World Energy Outlook - 2011, International Energy Agency, 2011.

R. Dones, C. Bauer and A. Röder, in Sachbilanzen von Energiesystemen: Grundlagen für den ökologischen Vergleich von Energiesystemen und den Einbezug von Energiesystemen in Ökobilanzen für die Schweiz. Final report ecoinvent No. 6-VI, ed. R. Dones, Paul Scherrer Institut Villigen, Swiss Centre for Life Cycle Inventories, Dübendorf, CH., v2.0 edn., 2007. 
33 World Intellectual Property Organization, WO Pat., 2004/039927 Al, 2004.

$50734 \quad$ S. Mukherjee and P. Borthakur, Fuel, 2001, 80, 2037-2040.

$50835 \quad$ R. T. Yang and K. Das, Fuel, 1985, 64, 735-742.

$50936 \quad$ K. M. Steel and J. W. Patrick, Fuel, 2001, 80, 2019-2023.

$51037 \quad$ J. Gulen, I. Doymaz, S. Piskin and S. Toprak, Energy sources, 2005, 27, 1457-1464.

51138 S. Mukherjee, S. Mahiuddin and P. Borthakur, Energy \& fuels, 2001, 15, 1418-1424.

39 R. Frischknecht, N. Jungbluth, H.-J. Althaus, G. Doka, R. Dones, T. Heck, S. Hellweg, R. Hischier, T. Nemecek, G. Rebitzer and M. Spielmann, Int. J. Life Cycle Assess., 2004, 10, 39.

$51540 \quad$ S. Channiwala and P. Parikh, Fuel, 2002, 81, 1051-1063.

41 W. Graus, M. Roglieri, P. Jaworski and L. Alberio, Efficiency and capture-readiness of new fossil power plants in the EU, European Commission, Utrecht, 2008.

42 US Environmental Protection Agency, Dewatering Municipal Wastewater Sludges,

E. Molina Grima, E.-H. Belarbi, F. G. Acién Fernández, a Robles Medina and Y. Chisti, Biotechnol. Adv., 2003, 20, 491-515.

44 Beckart Environmental, http://www.beckart.com/wastewater_treatment/batch_filter_presses.php, (accessed March 2015).

I. C. Kemp, in Modern Drying Technology, eds. E. Tsotsas and A. S. Mujumdar, Wiley-VCH Verlag GmbH \& Co. KGaA, 2011, pp. 1-45.

A. Nabeel, T. A. Khan and D. K. Sharma, Energy Sources, Part A Recover. Util. Environ. Eff., 2009, 31, 594-601.

GEA Filtration, http://www.geafiltration.com/applications/caustic_recovery_citrus_industry.asp, (accessed March 2015). Process. Technol., 2002, 79, 273-279.

$53550 \quad$ K. M. Steel and J. W. Patrick, Fuel, 2003, 82, 1917-1920. 
51 T. D. Wheelock and R. Markuszewski, in The Science and Technology of Coal and Coal Utilization, eds. B. R. Cooper and W. A. Ellingson, Plenum Press, New York, 1st edn., 1984, pp. 47-123.

52 R. Dones, X. I. N. Zhou and C. Tian, in Integrated Assessment of Sustainable Energy Systems in China, The China Energy Technology Program, eds. B. Eliasson and Y. Lee, Springer-Science+Business Media, BV, 1st edn., 2003.

53 R. Heijungs, Int. J. Life Cycle Assess., 2010, 15, 511-520.

54 W. W.-G. Yeh, Water Resour. Res., 1986, 22, 95-108.

55 P. Cohen, S. G. West and L. S. Aiken, Applied Multiple Regression/Correlation Analysis for the Behavioral Sciences, Taylor and Francis, 2nd edn., 2014.

56 Z. J. N. Steinmann, M. Hauck, R. Karuppiah, I. J. Laurenzi and M. a. J. Huijbregts, Int. J. Life Cycle Assess., 2014, 19, 1146-1155.

57 R. A. Johnson, Miller \& Freund's Probability and statistics for engineers, Pearson PrenticeHall, 2005.

58 S. Gavankar, S. Suh and A. A. Keller, J. Ind. Ecol., 2014, 00, n/a-n/a.

59 V. Letschert, L.-B. Desroches, J. Ke and M. McNeil, Energy, 2013, 59, 72-82.

60 D. Saygin, M. K. Patel, E. Worrell, C. Tam and D. J. Gielen, Energy, 2011, 36, 5779-5790.

61 C. Walsh and P. Thornley, J. Clean. Prod., 2012, 23, 138-146.

62 J. R. Duflou, J. W. Sutherland, D. Dornfeld, C. Herrmann, J. Jeswiet, S. Kara, M. Hauschild and K. Kellens, CIRP Ann. - Manuf. Technol., 2012, 61, 587-609.

63 N. Pouransari, M. Mercier, G. N. Sauvion and F. Maréchal, A general methodology for energy efficiency of industrial chemical processes, Elsevier, 2014, vol. 34.

64 E. Worrell, L. Bernstein, J. Roy, L. Price and J. Harnisch, Energy Effic., 2009, 2, 109-123.

65 N. Diaz, M. Helu, A. Jarvis, S. Tönissen, D. Dornfeld and R. Schlosser, Proc. MTTRF 2009 Annu. Meet., 2009.

6 A. Riaz, G. Zahedi and J. J. Klemeš, J. Clean. Prod., 2013, 57, 19-37.

67 S. Mukherjee, Energy \& fuels, 2003, 17, 559-564.

68 NDRC, Interim Measures on the Management of Commercial Coal Quality (Chinese), National Development and Reform Commision, People's Republic of China, 2014. 
69 NCC, Reliable \& Resilient The Value of Our Existing Coal Fleet An Assessment of Measures to Improve The Value of Our Existing Coal Fleet Reliable \& Resilient, The National Coal Council, 2014. 